\title{
The relationship between operating risk and accounting conservatism: Evidence from Iranian banking industry
}

\author{
Mehdi Taghavi $^{\mathrm{a}}$, Mohammad Khodaei Valahzaghard ${ }^{\mathrm{b}^{* *}}$ and Akram Ahmadloo ${ }^{\mathrm{c}}$
}

\begin{abstract}
${ }^{a}$ Prof., Department of Management, School of Management and Human Sciences, Tehran North Branch, Islamic Azad University (IAU), Tehran, Iran
${ }^{b}$ Assist. Prof. \& Faculty Member, Department of Accounting, School of Management and Human Sciences, Tehran North Branch, Islamic Azad University (IAU), Tehran, Iran

${ }^{c}$ M.Sc. Student, Department of Management, School of Management and Human Sciences, Tehran North Branch, Islamic Azad University (IAU), Tehran, Iran

\section{H R O N I C L E}

Article history:

Received October 28, 2013

Received in revised format

25 November 2013

Accepted 29 January 2014

Available online

January 312014

Keywords:

Operating Risk

Accounting Conservatism

Asset Volatility

A B S T R A C T

The purpose of this study is to analyze the relationship between operational risk and accounting conservatism. The criterion used for operational risk in this study is asset volatility and for accounting conservatism, we use Ball and Shivakumar (2005) model [Ball, R., \& Shivakumar, L. (2005). Earnings quality in UK private firms: comparative loss recognition timeliness. Journal of Accounting and Economics, 39(1), 83-128.], which analyzes accounting from balance sheet sight. The statistical society used in this study is taken from 15 banks in Tehran Stock Exchange over the period 2006-2012. The research result demonstrates that there was a negative relationship between operational risk and accounting conservatism. In other words, there is a significant negative relationship between operational risk and accounting conservatism. Hence, the results suggest that with an increase (decrease) in operational risk, accounting conservatism decreases (increases).
\end{abstract}

\section{Introduction}

One of the interesting issues on accounting affairs is to reduce any possible risk associated with various financial activities, which forces organizations to become more conservative and there are many studies associated with it (Beaver \& Ryan, 2000; Marshall \& Marshall, 2001; Grose, 1987). According to Watts (2003) "conservatism is defined as the differential verifiability required for recognition of profits versus losses". Ahmed et al. (2002) investigated the role of accounting conservatism in mitigating bondholder-shareholder conflicts over dividend policy and in reducing debt costs and reported that firms facing more severe conflicts over dividend policy would more likely use conservative accounting. The quality of earnings plays essential role on building high

*Corresponding author. Tel: +98-912-3443139

E-mail addresses: m khodaei@iau-tnb.ac.ir (M. Khodaei Valahzaghard) 
reputation on stock exchange since many investors may rely on giving more price appreciation when they see precise earnings estimates (Ball \& Shivakumar, 2005).

Bhattacharya et al. (2003) investigated financial statements from 34 countries over the period 19841998 to build a panel data set measuring 3 dimensions of reported accounting earnings for each country including earnings aggressiveness, loss avoidance, and earnings smoothing. They hypothesized that these three dimensions were associated with uninformative or opaque earnings, and so they combined them to obtain an overall earnings opacity time-series measure per country. They reported that, after controlling for other influences, an increase in overall earnings opacity in a country was associated with an economically substantial increase in the cost of equity and an economically substantial decrease in trading in the stock market of that country. Giner and Reverte (2006) analyzed the relevance of accounting fundamentals to inform about equity risk as measured by the expense of equity capital. They also highlighted the significance of investing risk, which has been ignored in previous research.

Feltham and Ohlson (1995) proposed a method to study the relationship between a firm's market value and accounting data concerning operating and financial activities. Givoly and Hayn (2000) documented the changes in the patterns of earnings, cash flows and accruals over the period 19602000. They investigated a number of measures of reporting conservatism in the absence of a generally accepted definition of conservatism. These measures depend on the accumulation of nonoperating accruals, the timeliness of earnings with respect to either bad or good news, characteristics of the earnings distribution and the market-to-book ratio. The patterns were consistent with an increase in conservative financial reporting over time. The findings had some implications for accounting standard setting, regulation of financial information and financial statement analysis.

Givoly et al. (2007) investigated the power and reliability of the differential timeliness (DT) measure to gauge reporting conservatism. They identified certain characteristics of the information environment unrelated to conservatism, which influences the DT measure and determined that it was sensitive to the degree of uniformity in the content of the news during the investigation period, the kinds of events happening in the period, and firms' disclosure policies. They reported that assessing the extent of reporting conservatism using this measure needs the recognition of, and control for, these characteristics. They also reported that the difference in the timeliness of reporting bad versus good news was likely to be more pronounced than previously reported. Further, they provided additional evidence on the negative association between the DT measure and alternative aspects of conservatism, implying that the exclusive reliance on any single measure to evaluate the overall conservatism of a reporting regime was likely to direct to incorrect inferences.

Khan and Watts (2009) estimated a firm-year measure of accounting conservatism, tested its empirical properties as a metric, and illustrated applications by examining new hypotheses that shed further light on the nature and impacts of conservatism. The results were consistent with the measure, capturing variation in conservatism and forecasting asymmetric earnings timeliness at horizons of up to 3 years ahead. They also reported that firms with longer investment cycles, higher idiosyncratic uncertainty and higher information asymmetry had higher accounting conservatism. Event studies implied increased conservatism was a response to increase in information asymmetry and idiosyncratic uncertainty.

Penman and Zhang (2002) developed diagnostic measures of this joint influence of investment and conservative accounting and reported that these measures could predict differences in future return on net operating assets relative to current return on net operating assets. Moreover, these measures also predicted stock returns - stating that investors would not appreciate how conservatism and changes in investment combined with raise questions about the quality of reported earnings. Ruddock et al. (2006) investigated whether the provision of non-audit services (NAS) by incumbent auditors was 
associated with a reduction in the extent to which earnings reflect bad news on a timely basis. Using various methods for detecting news-based conservatism, they consistently determined that higher than expected levels of NAS would not necessarily associated with reduced conservatism. The result was robust to permitting for endogenous NAS demand, as well as several explicit factors, which could be associated with differences in conservatism. Similar conclusions arise from investigations that apply alternative measures of the economic bond between auditors and their clients, as well as in tests confined to either the Big 6 or non-Big 6 audit firms.

Roychowdhury and Watts (2007) investigated the relationship between two extensively used measures of conservatism including asymmetric timeliness of earnings and the market-to-book ratio (MTB). They reported that when asymmetric timeliness was measured cumulatively over long periods, its relationship with end-of-period MTB was positive. When asymmetric timeliness was measured over short periods, its dependence on beginning-of-period composition of equity value (EV) was also responsible for its negative association with MTB. Shackelford and Shevlin (2001) traced the development of archival, microeconomic-based, empirical income tax research in accounting from 1985 to 2000 . According to Wang et al. (2008) described different measures and, within the constraints imposed by the limited and mixed relevant evidence and indicated that while the available evidence is insufficient to make a conclusion on construct validity, the analysis of this paper nevertheless implies that the construct validity of the five existing measures of conservatism was weak. Li (2010) investigated the contracting advantages of accounting conservatism on international debt and equity markets and reported that firms domiciled in countries with more conservative financial reporting systems had substantially lower cost of debt and equity, after controlling for differences in legal institutions and securities regulations.

\section{The proposed study}

This paper analyzes the relationship between operational risk and accounting conservatism. The criterion used for operational risk in this study is asset volatility and for accounting conservatism, the study uses Ball and Shivakumar (2005) model, which analyzes accounting from balance sheet sight. The statistical society used in this study is taken from 15 banks in Tehran stock exchange over the period 2006-2012. The volatility on assets $\left(V O L_{i t}\right)$ is measured as follows,

Asset Volatility $(V O L)=S D\left(A_{S S E T}, t-1, t-2\right) /$ Asset $_{t}$,

where $S D\left(A S S E T_{t, t-1, t-2)}\right.$ represents standard deviation on the last three years of total assets. Let $\mathrm{ACC}_{\mathrm{it}}$ represents total current accruals, which is calculated as the difference between operating profit and operating cash flow $\left(C F O_{i t}\right)$. Let $D C F O_{i t}$ be a dummy variable, which is equal to one if $C F O_{i t}<0$ and zero, otherwise. Therefore, we have,

$$
\begin{gathered}
A C C_{i t}=\alpha_{0}+\beta_{1} D_{C F O_{i t}}+\beta_{2} C F O_{i t}+\beta_{3} V O L_{i t}+\beta_{4} V O L_{i t} D C F O_{i t}+\beta_{5} V O L_{i t} C F O_{i t} \\
+\beta_{6} V_{i t} D C F O_{i t} C F O_{i t}+\varepsilon_{i t}
\end{gathered}
$$

Table 1 shows details of some basic statistics associated with the date we gathered. In addition, we present details of correlations ratios among various independent variables of the survey.

Table 1

The summary of some basic statistics

\begin{tabular}{cccccc}
\hline Variable & Number & Min & Max & Mean & Std Dev. \\
\hline$($ ACC $)$ & 105 & -104774 & 19803 & -1445 & 12081 \\
$($ CFO $)$ & 105 & -9768 & 106312 & 5238 & 13208 \\
$($ VOL $)$ & 105 & 0 & 1.03 & 0.1382 & 0.141 \\
\hline
\end{tabular}


Table 2

The summary of correlation ratios

\begin{tabular}{ccccc}
\hline Variable & & CFO & ACC & VOL \\
\hline CFO & r & 1 & -0.333 & 0.1359 \\
& Sig. & - & 0.359 & 0.167 \\
\hline ACC & r & -0.333 & - & -0.1134 \\
& Sig. & 0.359 & -0.1134 & 0.249 \\
\hline VOL & r & 0.1359 & 0.249 & 1 \\
& Sig. & 0.167 & & - \\
\hline
\end{tabular}

As we can observe from the results of Table 2, there is not any meaningful correlation among independent variables. We have also used VIF test to find out whether there is any linear relationship between independent variables or not and Table 3 shows details of our findings.

Table 3

The summary of VIF test

\begin{tabular}{lcc}
\hline Variable & VIF & $1 / \mathrm{VIF}$ \\
\hline CFO & 14.02 & 0.071 \\
DCFO & 4.23 & 0.236 \\
VOL & 1.38 & 0.722 \\
VOL $\times$ CFO & 14.81 & 0.067 \\
DVOL $\times$ CFO & 7.02 & 0.142 \\
VOL $\times$ DVOL $\times$ CFO & 3.14 & 0.318 \\
\hline Mean & 7.43 & - \\
\hline
\end{tabular}

The results of Table 3 show that most of the VIF numbers are well below 10, which means there is not any strong linearity between different pairs of independent variables. Next, we need to make sure that all data are normally distributed. The implementation of Kolmogorov-Smirnov has revealed that all data are normally distributed. Table 4 demonstrates the summary of our computations, which indicates that the data is normally distributed. Note that the implementation of regression analysis yields 1.91 for Durbin-Watson, which means there is no auto-correlation among residuals. Finally, Table 5 demonstrates the results of our regression analysis.

Table 4

The results of Kolmogorov-Smirnov test

\begin{tabular}{lcc}
\hline Variable & $Z$ & Sig. \\
\hline ACC & 0.969 & 0.304 \\
\hline
\end{tabular}

Table 5

The summary of regression analysis

\begin{tabular}{lcccc}
\hline Variable & $\beta$ & Std. Dev. & t-student & P-value \\
\hline CFO & -0.39 & 0.104 & -3.75 & 0.000 \\
DCFO & 5045 & 2284.5 & 2.21 & 0.027 \\
VOL & 7029 & 3062.5 & 2.3 & 0.022 \\
VOL $\times$ CFO & -2.42 & 0.547 & -4.43 & 0.000 \\
VOL $\times$ DCFO & -47179.68 & 16627 & -2.84 & 0.005 \\
VOL $\times$ DCFO $\times$ CFO & -7.47 & 2.23 & -3.35 & 0.001 \\
Intercept & 1696.5 & 581.71 & 2.92 & 0.004 \\
\hline
\end{tabular}

As we can observe from the results of Table 5, there is a negative and meaningful relationship between operating cash flow and conservatism $(\beta=-7.47)$ in accounting affairs, which confirms the main hypothesis of the survey. In other words, there is a significant negative relationship between 
operational risk and accounting conservatism. Hence, the results suggest that with an increase (decrease) in operational risk, accounting conservatism decreases (increases).

\section{Conclusion}

The purpose of this study is to analyze the relationship between operational risk and accounting conservatism. The study has accomplished in banking industry in Iran and the results have indicated that there was a negative relationship between operational risk and accounting conservatism. In other words, there is a significant negative relationship between operational risk and accounting conservatism. Hence, the results suggest that with an increase (decrease) in operational risk, accounting conservatism decreases (increases).

\section{Acknowledgement}

The authors would like to thank the anonymous referees for constructive comments on earlier version of this paper.

\section{References}

Ahmed, A. S., Billings, B. K., Morton, R. M., \& Stanford-Harris, M. (2002). The role of accounting conservatism in mitigating bondholder-shareholder conflicts over dividend policy and in reducing debt costs. The Accounting Review, 77(4), 867-890.

Ball, R., \& Shivakumar, L. (2005). Earnings quality in UK private firms: comparative loss recognition timeliness. Journal of Accounting and Economics, 39(1), 83-128.

Basu, S. (1997). The conservatism principle and the asymmetric timeliness of earnings. Journal of Accounting and Economics, 24(1), 3-37.

Beaver, W. H., \& Ryan, S. G. (2000). Biases and lags in book value and their effects on the ability of the book-to-market ratio to predict book return on equity. Journal of Accounting Research, 38(1), 127-148.

Bhattacharya, U., Daouk, H., \& Welker, M. (2003). The world price of earnings opacity. The Accounting Review, 78(3), 641-678.

Feltham, G. A., \& Ohlson, J. A. (1995). Valuation and clean surplus accounting for operating and financial activities. Contemporary accounting research, 11(2), 689-731.

Giner, B., \& Reverte, C. (2006). The risk-relevance of accounting data: Evidence from the Spanish Stock Market. Journal of International Financial Management \& Accounting, 17(3), 175-207.

Givoly, D., \& Hayn, C. (2000). The changing time-series properties of earnings, cash flows and accruals: Has financial reporting become more conservative? Journal of Accounting and Economics, 29(3), 287-320.

Givoly, D., Hayn, C. K., \& Natarajan, A. (2007). Measuring reporting conservatism. The Accounting Review, 82(1), 65-106.

Grose, V. L. (1987). Managing Risk: Systematic Loss Prevention for Executives. Prentice-Hall.

Khan, M., \& Watts, R. L. (2009). Estimation and empirical properties of a firm-year measure of accounting conservatism. Journal of Accounting and Economics, 48(2), 132-150.

Marshall, C. L., \& Marshall, D. C. (2001). Measuring and managing operational risks in financial institutions: tools, techniques, and other resources. John Wiley.

Penman, S. H., \& Zhang, X. J. (2002). Accounting conservatism, the quality of earnings, and stock returns. The Accounting Review, 77(2), 237-264.

Roychowdhury, S., \& Watts, R. L. (2007). Asymmetric timeliness of earnings, market-to-book and conservatism in financial reporting. Journal of Accounting and Economics, 44(1), 2-31.

Ruddock, C., Taylor, S. J., \& Taylor, S. L. (2006). Nonaudit services and earnings conservatism: Is auditor independence impaired?. Contemporary Accounting Research, 23(3), 701-746. 
Shackelford, D. A., \& Shevlin, T. (2001). Empirical tax research in accounting. Journal of Accounting and Economics, 31(1), 321-387.

Wang, R., Ó Hogartaigh, C., \& Van Zijl, T. (2008). Measures of accounting conservatism: A construct validity perspective. Journal of Accounting Literature, Forthcoming.

Watts, R. L. (2003). Conservatism in accounting part I: Explanations and implications. Accounting horizons, 17(3), 207-221.

Li, X. (2010, July). Accounting Conservatism and Cost of Capital: International Analysis. Financial Accounting and Reporting Section (FARS). 